DOI https://doi.org/10.36059/978-966-397-160-5/67-82

\title{
INNOVATIVE APPROACHES OF INTEGRATED COMMUNICATION CAMPAIGNS
}

\section{Svitlana Vavilina}

\section{INTRODUCTION}

A comprehensive communication strategy constitutes the basis of a communication campaign in the modern media landscape. Two-way communication consists of transmitting, receiving and processing of information which result in the established connection between a sender and a receiver ${ }^{1}$. This outcome demands an active perception of a particular message. However, communication noise and such factors as sender characteristics, context of social environment, relationship between source and receiver, receiver personal background and values as well as effects of a communication channel influence the way in which the message is interpreted and absorbed ${ }^{2}$.

New challenges to communication have emerged recently with media fragmentation, the rise of the Internet and digitization of media. The variety of available channels and media outlets implies that the audience is fragmented and difficult to reach. This trend is even more evident on social media where audiences are scattered across numerous general and niche social networking sites. Moreover, technology has made it possible for individuals to use multi-functional devices, meaning that communicators have to engage their target groups through multiple portals like smartphones, smartwatches and tablets. Digitization has also equipped consumers with tools and software to block or filter advertising messages and provided them with unprecedented supply of information about brands and services ${ }^{3}$. With the Web being transformed into a social platform, individuals are wielding tremendous power by assuming the active role in the value creation process. To reach this type of customer, organizations need to expand the focus from

${ }^{1}$ Clow, K. E., \& Baack, D. (2018). Integrated advertising, promotion, and marketing communications. Harlow: Pearson Education Limited. P. 36.

${ }^{2}$ Tench, R., \& Yeomans, L. (2007). Exploring public relations. Harlow, England: FT Prentice Hall. P. 145-146.

3 A best practice guide for developing communication campaigns (2013). Retrieved October 2, 2019, from http://www.culturehive.co.uk/resources/a-best-practice-guide-fordeveloping-communication-campaigns/. P. 3. 
product to their audiences' concerns and fulfil the human spirit through the goods or services they promote ${ }^{4}$.

Against this background, some organizations and advertisers have moved to the innovative approaches to speak in a clear voice and be heard by their customers and the general public. Their communication strategies are aimed at the omni-channel customer engagement which involves the integrated combination of the simultaneous use of multiple channels ${ }^{5}$. The outcome of an integrated campaign directly depends on the impact of the media multiplier effect ${ }^{6}$ that occurs only when each channel has a specific task in achieving the overall objective and "works harder because of the presence of the others" ". To provide meaningful insights across multiple channels, each piece of campaign should be consistent about the same creative idea that drives the development process $^{8}$. Understanding psychology behind the consumer is equally important since the messages delivered in novel and thought-inspiring ways are tend to be shared by the audience ${ }^{9}$ and contribute to creating emotional bonds between an organization and a consumer ${ }^{10}$.

This paper provides an analysis of a highly acclaimed the Imaginary Friend Society campaign produced by the advertising agency RPA (USA) for the Pediatric Brain Tumor Foundation and launched on September, 24, 2017. The Imaginary Friend Society was awarded two Gold Lions at the Cannes Lions International Festival of Creativity (2018) in the category of Health and Wellness, one being for Integrated Campaign and the other for Branded Content and Entertainment. The campaign also won the 2018 Gold Jay Chiat Award for Non-profit Strategy. This research explores the components of the RPA break-through communication strategy as well as advertising tools employed to make a positive impact on the public perception of such a dreadful issue as pediatric cancer.

${ }^{4}$ Onete, C. B., Albăstroiu, I., \& Dina, R. (2017). Consumer between Web 2.0 and Web 3.0. Consumer Behavior - Practice Oriented Perspectives, 29-43. doi: 10.5772/intechopen.71268. P. 34-35

${ }^{5}$ Ibid. P. 31

${ }^{6}$ Clow, K. E., \& Baack, D. (2018). Integrated advertising, promotion, and marketing communications. Harlow: Pearson Education Limited. P. 231.

7 A best practice guide for developing communication campaigns (2013). Retrieved October 2, 2019, from http://www.culturehive.co.uk/resources/a-best-practice-guide-fordeveloping-communication-campaigns/. P. 10

${ }^{8}$ Clow, K. E., \& Baack, D. (2018). Integrated advertising, promotion, and marketing communications. Harlow: Pearson Education Limited. P. 32

${ }^{9}$ Greenwald, M. (2017, March 20). Secrets Of 7 Of The Most Effective Ad Campaigns. Retrieved October 1, 2019, from https://www.forbes.com/sites/michellegreenwald/ 2014/07/10/secrets-of-7-of-the-most-effective-ad-campaigns/\#51836468320c.

${ }^{10}$ Onete, C. B., Albăstroiu, I., \& Dina, R. (2017). Consumer between Web 2.0 and Web 3.0. Consumer Behavior - Practice Oriented Perspectives, 29-43. doi: 10.5772/ intechopen.71268. P. 35. 


\section{Components of the communication strategy}

The most essential element of a communication strategy is the objective which is essential for planning a complicated process of "multi-channel, multi-content, often multi-market" building awareness, providing information and creating imagery, it should be aligned with commercial goals and well-thought-out distribution policy ${ }^{12}$. The objective that the Pediatric Brain Tumor Foundation set for RPA was to create quality pro bono marketing materials that could explain cancer treatment procedures to children. A recent survey ${ }^{13}$ of parents and other adults connected with pediatric cancer as well as former pediatric cancer patients revealed that there is a serious lack of adequate resources geared towards children diagnosed with brain tumors or other cancers to help them cope with fear of medical treatment and anxiety caused by complex medical terminology.

Instead of producing a typical awareness campaign targeting adults, the agency saw an opportunity to address the children themselves. The inspiration came from meeting real pediatric cancer survivors at the Pediatric Brain Tumor Foundation events. The children told the agency researchers that they had imaginary friends who helped them endure long hospital stays $^{14}$. The RPA's original idea was to "unite" those imaginary friends into the animated "society" whose members would speak a language that sick children could understand and relate to. Having an engaging idea at the heart of the communication strategy is the only way to get people involved ${ }^{15}$ and RPA's aspiration to meet a specific need for the youngest patients by creating delightful educational cartoons about complicated aspects of cancer treatment proved to be a really integrating one.

This idea worked as a "steel thread" to unify the messaging across all of the marketing content and helped to gain support from other organizations who collaborated for its successful execution ${ }^{16}$. According to Jason Sperling, RPA's Senior Vice President, the latter presented a real challenge because

11 A best practice guide for developing communication campaigns (2013). Retrieved October 2, 2019, from http://www.culturehive.co.uk/resources/a-best-practice-guide-fordeveloping-communication-campaigns/. P. 5

${ }^{12}$ Ibid.

${ }^{13}$ Infographic. Retrieved from https://www.imaginaryfriendsociety.com/infographic.

${ }^{14}$ Ovsyannikova, D. (2018, June 14). New Campaign: Imaginary Friend Society. Retrieved October 1, 2019, from https://ru.adforum.com/interviews/ar-imaginary-friend-society.

15 A best practice guide for developing communication campaigns (2013). Retrieved October 2, 2019, from http://www.culturehive.co.uk/resources/a-best-practice-guide-fordeveloping-communication-campaigns/. P. 7.

${ }^{16} 6$ Elements of a Truly Integrated Campaign. (2019, August 21). Retrieved October 1, 2019, from https://insights.newscred.com/6-elements-of-a-truly-integrated-campaign/. 
the agency "had to find animation companies that would be willing to donate the time, energy and resources to the project for free" 17 .

Several different production, animation and sound-design companies from all over the world were pleased and honored to be invited to participate in the campaign and pushed themselves hard "to construct something remarkable" $"$. Collectively, this partnership brought their own unique imaginary friends to life in a series of 22 animated films that feature various experiences children and their relatives face with a cancer diagnosis. What had started with the films was later extended to the Augmented Reality (AR) application aimed to make upcoming medical procedures feel less frightening by allowing small patients to hear words of encouragement from their favorite cartoon characters during difficult times. Moreover, the coloring books, posters, journals and stuffed Imaginary Friends dolls were designed to brighten up hospital rooms and give comfort throughout the treatment. The Pediatric Brain Tumor Foundation initiated the Imaginary Friend Society website ${ }^{19}$ to make the films available online and to provide the young patients with the option to donate their own imaginary friends to the campaign.

The idea also brought together child life specialists, social workers and medical staff throughout the United States as well as other childhood cancer nonprofits who joined the Pediatric Brain Tumor Foundation in distributing the films across the United States leading hospitals, social channels and directly families undergoing treatment.

Bringing in new teams and additional channels to the fold allowed the Imaginary Friend Society campaign to achieve a silo-busting effect ${ }^{20}$ that resulted in breaking down collaboration barriers and becoming truly integrated. All teams within integrated campaigns work together in the interest of customer needs by harmonizing information and activities across the collaborative mix.

The coordinated efforts resulted in receiving astonishing $\$ 1 \mathrm{MM}$ in media value and more than 46.3MM PR impressions in top-ranked Designated Market Areas without spending a single media dollar ${ }^{21}$. This is further proof

${ }^{17}$ Ovsyannikova, D. (2018, June 14). New Campaign: Imaginary Friend Society. Retrieved October 1, 2019, from https://ru.adforum.com/interviews/ar-imaginary-friend-society.

${ }^{18}$ Gentleman Scholar Contributes "Welcome to the Imaginary Friend Society" Short Film For RPA's Thoughtful Campaign For The Pediatric Brain Tumor Foundation. Retrieved October 1, 2019, from https://www.shootonline.com/spw/gentleman-scholar-contributeswelcome-imaginary-friend-society-short-film-rpas-thoughtful.

${ }^{19}$ Imaginary Friend Society. (n.d.). Retrieved from https://www.imaginaryfriendsociety.com/.

${ }^{20} 6$ Elements of a Truly Integrated Campaign. (2019, August 21). Retrieved October 1, 2019, from https://insights.newscred.com/6-elements-of-a-truly-integrated-campaign/.

21 Imaginary Friend Society. Retrieved October 1, 2019, from https://www.deconstructedbrief.com/imaginary-friend-society. 
that "hugely ambitious objectives are frequently attempted with absurdly small budgets",22.

Finding ways to influence the consumer is another vital ingredient for the effective communication strategy. The consumer need (physical or psychological) warrants the information search process which can be utilized by three models: attitudes, values and cognitive mapping ${ }^{23}$. To reach the target audience the communication campaign planners need either confirm or change the consumer attitudes or actions ${ }^{24}$. Attitudes reflect their holders' positions toward a certain topic or event and influence their feelings, perceptions, learning processes and subsequent behavior ${ }^{25}$.

There are three elements that comprise a consumer attitude: cognitive, affective and conative ${ }^{26}$, which are also perceived as levels where strategic objectives are set $\mathrm{at}^{27}$. The cognitive element relates to thoughts or mental images of the problem or issue and is aimed at inspiring the target public to think about the topic or create awareness. The affective component refers to feelings or emotional reactions to a topic or idea, so the objective being set at this level aims to encourage the target audience to form a particular opinion or feeling about the subject. The conative component contains the intentions, behavior or actions and is geared towards change in the consumers behavior $^{28}$. The most common sequence of events that takes place in attitude formation is from the cognitive component, through the affective one and, finally, to the conative element ${ }^{29}$.

Attitudes are framed by values or strong beliefs about topics or concepts. Although being tend to endure, values can change over time due to different life experiences. Additionally, such factors as personality characteristics, temperament, social environment and culture affect personal values or the degree to which they are hold. ${ }^{30}$ The value-oriented marketing treats consumers as "human beings in their entirety, with mind, heart and soul

22 A best practice guide for developing communication campaigns (2013). Retrieved October 2, 2019, from http://www.culturehive.co.uk/resources/a-best-practice-guide-fordeveloping-communication-campaigns/. P. 5.

${ }^{23}$ Clow, K. E., \& Baack, D. (2018). Integrated advertising, promotion, and marketing communications. Harlow: Pearson Education Limited. P. 79.

${ }^{24}$ Tench, R., \& Yeomans, L. (2007). Exploring public relations. Harlow, England: FT Prentice Hall. P. 192.

${ }^{25}$ Clow, K. E., \& Baack, D. (2018). Integrated advertising, promotion, and marketing communications. Harlow: Pearson Education Limited. P 79.

${ }^{26}$ Ibid.

${ }^{27}$ Tench, R., \& Yeomans, L. (2007). Exploring public relations. Harlow, England: FT Prentice Hall. P. 192.

${ }^{28}$ Ibid.

${ }^{29}$ Clow, K. E., \& Baack, D. (2018). Integrated advertising, promotion, and marketing communications. Harlow: Pearson Education Limited. P. 79.

${ }^{30}$ Ibid. P. 81. 
energies"31, which allows campaign planners to appeal to their audience's values by addressing the most profound human pursuits.

In terms of the Imaginary Friend Society campaign, the evidence-based need for the educational resources that could explain difficult aspects of cancer care to families and provide encouragement to children facing the wide array of invasive procedures compelled the specific audience to search for the relevant information ${ }^{32}$. Addressing this need, RPA faced the challenge of offering really useful materials that would stand out in a sea of homogeneous health care advertising based on traditional approaches and ideas. Reaching the target audience implied changing their attitude towards pediatric cancer treatment by making this daunting topic more accessible. The values needed an equal consideration and the agency took an unprecedented move to tie the campaign to such personal values as fun, exciting life, happiness, security, sense of belonging and social acceptance that are shared by all children regardless of whether they have cancer or not. What is more, the Imaginary Friend Society, like other great advertising campaigns, was founded on deep psychological insights ${ }^{33}$.

To make it possible for the marketing team to develop advertisements and relevant communication, they need to understand how people store, retrieve and evaluate information that will further affect their decisions. The use of cognitive maps enables campaign researchers to stimulate the knowledge structures rooted in an individual's mind ${ }^{34}$. These structures expose how personal assumptions, beliefs and attitudes about the world interpret new information and determine responses to a novel situation. Figure 1 depicts a hypothetical cognitive map of a child with cancer who gets bombarded with confusing information about disease and its treatment procedures.

${ }^{31}$ Onete, C. B., Albăstroiu, I., \& Dina, R. (2017). Consumer between Web 2.0 and Web 3.0. Consumer Behavior - Practice Oriented Perspectives, 29-43. doi: 10.5772/intechopen.71268. P. 35.

${ }^{32}$ Natividad, A. (2017, September 29). Kids With Cancer Get a Slew of Imaginary Friends to Help Them in Lovely Campaign From RPA. Retrieved October 1, 2019, from https://www.adweek.com/brand-marketing/kids-with-cancer-get-a-slew-of-imaginary-friendsto-help-them-in-lovely-campaign-from-rpa/

${ }^{33}$ Greenwald, M. (2017, March 20). Secrets Of 7 Of The Most Effective Ad Campaigns. Retrieved October 1, 2019, from https://www.forbes.com/sites/michellegreenwald/2014/07/10/ secrets-of-7-of-the-most-effective-ad-campaigns/\#51836468320c.

${ }^{34}$ Clow, K. E., \& Baack, D. (2018). Integrated advertising, promotion, and marketing communications. Harlow: Pearson Education Limited. P. 82. 


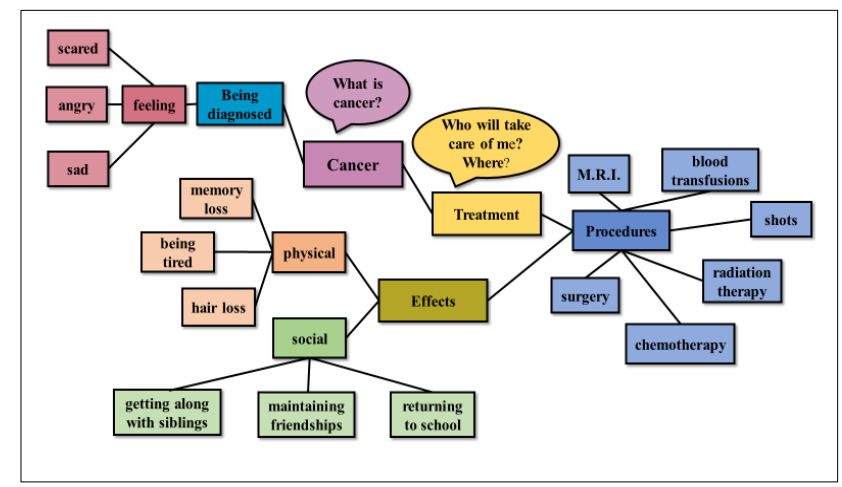

\section{Fig 1. A hypothetical cognitive map for the pediatric cancer treatment}

Based on the final creative content of the Imaginary Friend Society campaign, this map is made to reconstruct the probable pathways that a sick child's mind might follow in the wake of the horrible diagnosis as well as accompanying fears and apprehensions. The ambitious task of the campaign was to change children's and their relatives' attitude by creating a new linkage between the information provided and the concepts of cancer along with its medical, physical, emotional and social implications. The linkage is constructed when the consumer is persuaded by the advertisement, otherwise the information will be ignored or forgotten, and no new linkage occurs ${ }^{35}$.

Thus, cognitive mapping and persuasion techniques developed to change attitudes or tap into strongly hold values constitute key components of any integrated communication campaign. By providing an insight into the target group's needs, they allow creative teams to produce messages to meet those needs. To capture the consumers' attention, a message should expose them to concepts that proceed effectively throughout mental processing channels through logic or enticing emotional appeals ${ }^{36}$.

For many types of campaign messages are critically important. This is particularly true for public information campaigns like the Imaginary Friend Society which often use memorable messages. Messages are important for four main reasons. Firstly, they generate awareness and form attitudes. Secondly, they prove that the communication channels have been appropriate and that the message reached the recipient. Thirdly, the degree of

${ }^{35}$ Clow, K. E., \& Baack, D. (2018). Integrated advertising, promotion, and marketing communications. Harlow: Pearson Education Limited. P. 84.

${ }^{36}$ Clow, K. E., \& Baack, D. (2018). Integrated advertising, promotion, and marketing communications. Harlow: Pearson Education Limited. P. 85. 
the message assimilation helps to evaluate effectiveness of the campaign. Lastly, they allow to balance creativity and discipline within a marketing team $^{37}$. However, messages have limitations since they indicate the one-way communication. To initiate the dialogue with the audience the campaign should bring in carefully thought-through content that is an equally vital element of the integrated communication strategy.

The next chapter investigates the advertising techniques that RPA employed to design effective messages together with creative content and to bring the new dimensions into the public's perception of potentially traumatic aspects of childhood cancer.

\section{Advertising tools and design}

Designing a compelling and influential advertising campaign can be a challenging part of an integrated communication program. A successful advertising campaign results in changing people's attitudes and behaviors. To achieve such an effect, the message theme requires a tactical approach to its delivery. Message strategies fall into three categories: cognitive, affective, conative. These categories signify the components of attitudes as noted in the previous chapter. There are various forms of approaches within each category that are usually applied by advertisers to influence the consumer ${ }^{38}$.

Regarding the Imaginary Friend Society campaign, the advertisers definitely opted for the affective message strategies. Such strategies evoke feelings or emotions that affect consumers' reasoning processes and lead them to act. The two types of tactics within this category are resonance and emotional approach.

Resonance was used by RPA to develop stronger ties, or a "vibe", with the target audience. The series of films addressed the core needs of the young patients implicitly by creating approachable characters who belong solely to the children's world. The agency research showed that childhood cancer survivors often use imaginary friends as coping mechanisms during long hospital stays, with almost two-thirds $(65 \%)$ of children having an imaginary friend by the age of seven ${ }^{39}$. The films characters introduce themselves by the name (be it Captain Beakbeard in "What is Cancer?", Charlie and Roger in "What is an M.R.I", Mr. Spikes in "Blood Transfusions" or Shelly the Turtle in "Returning to School") and the phrase

${ }^{37}$ Tench, R., \& Yeomans, L. (2007). Exploring public relations. Harlow, England: FT Prentice Hall. P. 195.

${ }^{38}$ Clow, K. E., \& Baack, D. (2018). Integrated advertising, promotion, and marketing communications. Harlow: Pearson Education Limited. P. 176.

39 Imaginary Friend Society. Retrieved October 1, 2019, from https://www.deconstructedbrief.com/imaginary-friend-society. 
"I'm an imaginary friend of a kid just like you!" which resonates with children's need for reassurance and engages in conversation that reflects their values and interests. Throughout the videos these and other characters keep saying that they understand how a child might be feeling in a given situation, adding that it is all right to feel angry, scared, sad, confused, overwhelmed or "all of the above". They assure that "everyone gets sad" and "everyone feels scared" because "being sad (or scared) is part of life".

These messages reflect such personal value as a sense of belonging ${ }^{40}$ that could be under threat of avoidance and isolation after a child is diagnosed with cancer. To eliminate this threat, Ambassador Bob in the introductory film "Welcome to the Imaginary Friend Society" cautions a child against blaming himself for having done something wrong that might have caused the disease, because "nothing you did caused cancer". He explains that "it is just what happens to people" and not only to people, but also animals, fish and birds. Characters from other films convince that scars which might appear after surgery are "pretty cool", and that losing hair after chemotherapy or radiation treatment is the "chance to experiment with wigs or elevate your look with some different hat wear", and there is nothing to be embarrassed about possible memory loos after some procedures because "people around you will understand". This tactic is aimed at fostering the value of social acceptance ${ }^{41}$ and such promises substantially address children's aspirations to maintain social relationships.

The words of encouragement and strength from the cartoon characters help to develop supportive relationships with the target audience. We hear members of the Imaginary Friends Society trying to convince children that "they are stronger, than they know". Walt in "Radiation" jokingly calls a child he addresses from the screen "this brave young whippersnapper", whereas Pico who stars in "Being Scared" openly admires a young patient's courage. He says: "You are so strong! You are making me strong!" and promises that after every scary treatment a kid will come out even stronger. The mobile AR application deepens this bond by allowing children to bring characters to life whenever they feel the need of a "pep talk" during the treatment.

The affective resonance advertising always looks for the ways to engage the audience and solicit feedback. RPA's team came up with an idea to get children involved by inviting them to upload drawings of their own imaginary friends on their social media channel with hashtag "Imaginary

${ }^{40}$ Clow, K. E., \& Baack, D. (2018). Integrated advertising, promotion, and marketing communications. Harlow: Pearson Education Limited. P. 146/

${ }^{41}$ Clow, K. E., \& Baack, D. (2018). Integrated advertising, promotion, and marketing communications. Harlow: Pearson Education Limited. P. 146/ 
Friend Society". Later some of these pictures were turned into "posters, dolls and other fun things to help brighten up spirits of sick kids", just as Ambassador Bob had promised in the introductory film.

An emotional affective approach attempts to evoke powerful feelings that result in the boost of behavioral responses. What is more, emotional priming is considered to amplify the effects of rational messages ${ }^{42}$. Therefore, if advertisers can induce a sense of cognitive ease through the prism of emotions, the message is likely to be heard and assimilated. A comprehensive study by the Institute of Practitioners in Advertising (UK) revealed that effects of emotional campaigns last much longer that the ones of rational campaign and have a propensity to accumulate more strongly over time ${ }^{43}$. Besides being more than twice as efficient as rational campaigns, emotional affective strategies also deliver twice the profit.

Emotional appeals are based on suppositions that 1) consumers are tend to ignore most advertisements; 2) rational appeals generally remain unnoticed; 3) emotional appeals grab attention and foster an attachment ${ }^{44}$. RPA's creatives feature a wide range of emotions in their films. The very titles like "Feeling angry" and "Feeling sad" speak for themselves. A reasonable portion of self-indulgence appeal can be found in "Chemotherapy" episode whose character promises that going through the procedure will give you "a power over your family who will spoil you and treat like royalty".

The age of young patients necessitates happiness appeal that manifests itself in looking at the bright side. For example, the robot in "Why am I tired all the time?" advises a child to concentrate on easy-going activities like listening to music, doing some arts or reading books, which "can be as much fun as running about". However, it is visual representation that adds in children's delight. Experts believe that visual cues in advertisements are key components of emotional appeals ${ }^{45}$. Besides bright and bold colors, the films show a lot of symbols associated with fun and happiness like confetti, balloons, flickering lights, beach umbrellas and so on.

The Imaginary Friends behave as quite real ones saying to a child that "the Imaginary Friend Society always have your back". Thereby Mr. Tips is always there in case someone feels blue and the duo of Charlie and Roger keeps company "in boring places like hospitals". Ambassador Bob appeals

42 Binet, L. (2013). The long and the short of it. IPA. Retrieved from https://jeanallary.files.wordpress.com/2016/07/the_long_and_short_of_it_pdf_doc.pdf. P. 51.

${ }^{43}$ Ibid. P. 53.

${ }^{44}$ Clow, K. E., \& Baack, D. (2018). Integrated advertising, promotion, and marketing communications. Harlow: Pearson Education Limited. P. 190.

${ }^{45}$ Clow, K. E., \& Baack, D. (2018). Integrated advertising, promotion, and marketing communications. Harlow: Pearson Education Limited. P. 147. 
to friendship but also to family bonds when he reminds a child that he is not alone because his friends and family will be with him "every step of the way". Moreover, there is a separate film in the series titled "Help for Brothers and Sisters" to guide siblings of childhood cancer survivors through the perils of growing up in a family affected by cancer.

Among all emotions depicted in the movies, appeal that focuses on the need for security seems to be the most prominent. It finds expression in metaphorical explanations of medical procedures with constant emphasis on their importance for the successful treatment and future welfare. Being translated from the medical talk into a kid-talk, cancer treatment does not sound scary anymore. It is especially so, when a child is assured that the team which includes "the smartest of the smart" doctors, "the nicest of the nice" nurses, "the wisest of the wise" psychologists together with radiologists, social workers and cooks "who will be great of what they do and with their forces combined it's like having the hospital itself helping you out".

Emotions in the films are tied with humor and music to make the content more compelling. Such combination can influence the audience both emotionally and rationally.

The use of these techniques allowed RPA to change the attitude development by reversing the sequence and starting with affective persuasion, which led to conative consequences and, finally, resulted in the cognitive engagement to their messages. The agency and their partners made an attempt to construct new linkages between the information they provided and cancer-related concepts. As a result, new associations have been built. Thus, cancer is presented as a mutiny on a fairy-tail ship when "you've got a bad cell turning against a good one". An MRI machine is depicted as a space ship, on board of which a child "can explore a galaxy for a bit, take in a moon landing or drop on Mars, befriend an alien species". Chemotherapy has been turned into a brawny superhero who defeats bad cells with heavy blows, telekinesis and lasers. The character from "How to handle shots" recommends children "to teach your brain new ways to react" and asks them to befriend scary needles because they only want to be helpful. The whole period of cancer treatment is proposed to be taken as a roller-coaster ride "when the scariest part is the first climb up the big hill", but once it is over "you will feel invincible". The results of the survey by the Pediatric Brain Tumor Foundation prove that RPA's efforts have not been wasted as the majority of respondents who had seen the Imaginary Friends Society films, found them valuable for parents and caregivers talk with their children about difficult issues and agreed that the videos helped kids feel less anxious (with figures standing at $96 \%$ and $85 \%$ respectively $)^{46}$.

${ }^{46}$ Infographic. (n.d.). Retrieved from https://www.imaginaryfriendsociety.com/infographic. 
The choice of animation as an executional framework ${ }^{47}$ for conveying the message strategy of the Imaginary Friend Society campaign stems from the well-founded analysis of psychographic and demographic characteristics of the target audience. Besides, the technological affordances of the most advanced computer graphics programs allowed the animation studios involved in the project not only to create visually stunning imagery but also to experiment with different styles and techniques.

According to the representatives of the creative production company Gentleman Scholar, which worked on the introductory film "Welcome to the IFS", they "designed dozens of mixed-media characters who could live together" ${ }^{48}$ to embody the animations and different mediums of all other videos in the series. By using Autodesk Maya, a sophisticated 3D modelling software, accelerated by Redshift's rendering along with the Nuke editorial toolkit and powerful Adobe After Effects animation tools they brought to life more than 50 highly realistic characters who walk, fly, skate, slink and slide around the environments. Seventeen other reputable film and animation studios from the US, UK, Canada, Hungary and Poland put their expertise and unique visions to good use to create the series of videos, each of whom can be considered as a microcosm of an unparalleled imaginary world. The use of the cutting-edge 3D modelling as well as 2D animation ("What is cancer?", "Surgery"), motion graphics ("Radiation"), stop-motion animation with puppet characters ("Feeling angry") or combination of different animation types ("Who will be taking care of me?") makes each of the films like no other. We can also find 1930s retro futuristic sci-fi set in "Why am I tired all the time?", the touch of 1980s videogames in "Blood transfusions" and the style of comic books mimicked by cel shading in "Chemotherapy". 3D and 2D animation techniques have also found their application in a simple AR app for mobile devices and tablets that allows children to select any of the films' most lovable characters, adjust their size, place them in the hospital environments and interact with them as they offer words of encouragement during difficult times ${ }^{49}$. Most recently, RPA announced more sophisticated AR application that utilizes motion capture so that doctors and

${ }^{47}$ Clow, K. E., \& Baack, D. (2018). Integrated advertising, promotion, and marketing communications. Harlow: Pearson Education Limited. P. 191.

${ }^{48}$ Gentleman Scholar Contributes «Welcome to the Imaginary Friend Society» Short Film For RPA's Thoughtful Campaign For The Pediatric Brain Tumor Foundation. Retrieved October 1, 2019, from https://www.shootonline.com/spw/gentleman-scholar-contributeswelcome-imaginary-friend-society-short-film-rpas-thoughtful.

49 Imaginary Friend Society AR. Retrieved October 2, 2019, from https://toolofna.com/work/imaginary-friends-society-ar. 
nurses will be able to speak to pediatric cancer patients as a character from one of the videos ${ }^{50}$.

The success of an advertising campaign heavily relies on the source, or a spokesperson, who presents the advertising message verbally and/or visually. RPA's decision to reject such traditional spokespersons as experts (for example, doctors) or celebrities and select someone who was born in a child's own imagination in response to a desperate need for support and security made it possible to create a source that utilizes almost all characteristics of effective spokespersons ${ }^{51}$. Imaginary friends fully meet the requirements of credibility, attractiveness, similarity, likeability and trustworthiness. Surprisingly, they exhibit more expertise than educated experts in the medical field and therefore have more power in persuading the target audience of the young cancer patients.

Thus, the affective approach by RPA defined the use of resonance advertising and emotional methods. The logical combinations of various appeals promoted the utilization of the advertising messages. The manner of executional framework based on the insight on how children see the world helped translate abstract and foreign concepts into approachable stories, events and characters. All these advertising techniques in combination with well-planned communication strategy ensured the success of the Imaginary Friend society integrated campaign.

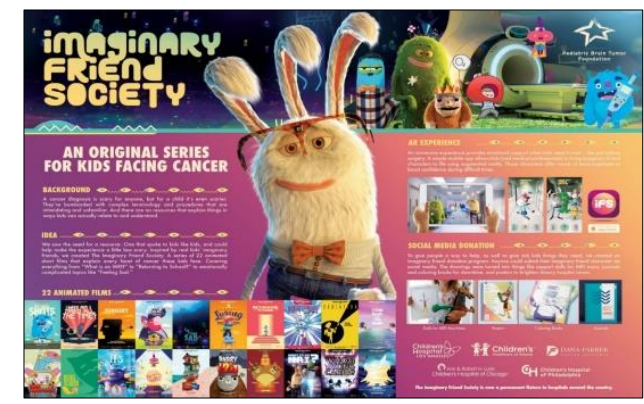

Fig. 2. Advertising materials for the Imaginary Friend Society campaign ${ }^{52}$

\footnotetext{
${ }^{50}$ Ovsyannikova, D. (2018, June 14). New Campaign: Imaginary Friend Society. Retrieved October 1, 2019, from https://ru.adforum.com/interviews/ar-imaginary-friend-society.

${ }^{51}$ Clow, K. E., \& Baack, D. (2018). Integrated advertising, promotion, and marketing communications. Harlow: Pearson Education Limited. P. 198.

52 "Pediatric Brain Tumor Foundation: Imaginary Friend Society." RSS, 1 Sept. 2018, https://www.adsoftheworld.com/media/integrated/pediatric_brain_tumor_foundation_imaginary _friend_society.
} 


\section{CONCLUSIONS}

Increasingly changing media landscape makes it more difficult for companies and organizations to communicate with their consumers. Such factors as media fragmentation, the rise of the Internet-enhanced interactive communities, the digitization of media and omni-channel consumer behavior require from organizations careful planning of their communication strategies. To reach the target audiences, they need to rely on customized approaches that engage their consumers in a conversation based on shared interests and values. Integrated communication campaigns bring together creative content and the media by paying attention to the content relevance and the role that different channels play in adapting the content, creative and format accordingly.

The analysis of the award-winning Imaginary Friend Society Campaign highlights the key components of an efficient integrated communication strategy. First of all, a truly integrated communication campaign has a clear objective aimed at solving the human problem. The unifying idea behind the objective boosts the collaboration between the partners and helps select media channels. It also allows the advertising agency to get access to top talents in the industry and reduce costs.

The insight on behavior contributes to developing relevant message strategies. Affective strategies based on resonance and emotional appeal prove to be the most efficient when it comes to changing attitudes towards such sensitive topics as pediatric cancer. The right choice of executional framework as well as the selection of the other ingredients including music, colors, motion and humor intensify various appeals within the message strategy. In addition, the quality of the advertising message is improved by relying on credibility, attractiveness, similarity, likeability, trustworthiness and expertise of the source.

Promising directions for further research lie in the developing educational materials for students of Ukrainian universities who major in Public Relations and Advertising to learn about the recent achievements and trends in the field.

\section{SUMMARY}

The study is to show how the shifting media landscape reshapes the way organizations communicate with their public. The main focus is on the innovative overseas practices in planning and conducting integrated communication campaigns. Through deconstructing a highly-acclaimed advertising campaign designed by the American advertising agency RPA for the Pediatric Brain Tumor Foundation, this research highlights the key elements of an integrated communication strategy. The aspects explored relate to the having a unifying idea to guide the objective and the choice of 
media channels as well as finding the ways to engage the target audience. The research draws upon the primary sources including 22 animated films, AR application and the Imaginary Friend Society website to examine the advertising tools and elements of advertising design employed by the agency and its creative partners to construct the compelling message. This case example shows that the insight on how children understand the world helped create an overreaching and cohesive narrative that remained with the audience outside the digital videos. The findings may be useful in educating Ukrainian students of Journalism, Public Relations and Advertising about recent trends in media relations.

\section{REFERENCES}

1. A best practice guide for developing communication campaigns (2013). Retrieved October 2, 2019, from http://www.culturehive.co.uk/ resources/a-best-practice-guide-for-developing-communication-campaigns/.

2. Binet, L. (2013). The long and the short of it. IPA. Retrieved from https://jeanallary.files.wordpress.com/2016/07/the_long_and_short_of_it_pd f_doc.pdf.

3. Clow, K. E., \& Baack, D. (2018). Integrated advertising, promotion, and marketing communications. Harlow: Pearson Education Limited.

4. Gentleman Scholar Contributes "Welcome to the Imaginary Friend Society" Short Film For RPA's Thoughtful Campaign For The Pediatric Brain Tumor Foundation. Retrieved October 1, 2019, from https://www.shootonline.com/spw/gentleman-scholar-contributes-welcomeimaginary-friend-society-short-film-rpas-thoughtful.

5. Greenwald, M. (2017, March 20). Secrets Of 7 Of The Most Effective Ad Campaigns. Retrieved October 1, 2019, from https://www.forbes.com/sites/michellegreenwald/2014/07/10/secrets-of-7of-the-most-effective-ad-campaigns/\#51836468320c.

6. Imaginary Friend Society. Retrieved from https://www.imaginaryfriendsociety.com/.

7. Imaginary Friend Society. Retrieved October 1, 2019, from https://www.deconstructedbrief.com/imaginary-friend-society.

8. Imaginary Friend Society AR. Retrieved October 2, 2019, from https://toolofna.com/work/imaginary-friends-society-ar.

9. Jardine, A. (2017, September 26). 'Imaginary Friends' Empower Cancer-Stricken Kids in This Touching Animated Campaign. Retrieved October 1, 2019, from https://adage.com/creativity/work/imaginary-friendsociety-finding-out-you-have-cancer/52773.

10. McAteer, O. (2018, December 5). What's to come for RPA's imaginary friends effort to help kids with cancer. Retrieved October 1, 2019, 
from https://www.campaignlive.com/article/whats-rpas-imaginary-friendseffort-help-kids-cancer/1461300.

11. Natividad, A. (2017, September 29). Kids With Cancer Get a Slew of Imaginary Friends to Help Them in Lovely Campaign From RPA. Retrieved October 1, 2019, from https://www.adweek.com/brand-marketing/kids-withcancer-get-a-slew-of-imaginary-friends-to-help-them-in-lovely-campaignfrom-rpa/.

12. Onete, C. B., Albăstroiu, I., \& Dina, R. (2017). Consumer between Web 2.0 and Web 3.0. Consumer Behavior - Practice Oriented Perspectives, 29-43. doi: 10.5772/intechopen.71268.

13. Ovsyannikova, D. (2018, June 14). New Campaign: Imaginary Friend Society. Retrieved October 1, 2019, from https://ru.adforum.com/interviews/ar-imaginary-friend-society.

14. "Pediatric Brain Tumor Foundation: Imaginary Friend Society." RSS, 1 Sept. 2018, https://www.adsoftheworld.com/media/integrated/ pediatric_brain_tumor_foundation_imaginary_friend_society.

15. 6 Elements of a Truly Integrated Campaign. (2019, August 21). Retrieved October 1, 2019, from https://insights.newscred.com/6-elementsof-a-truly-integrated-campaign/.

16. Tench, R., \& Yeomans, L. (2007). Exploring public relations. Harlow, England: FT Prentice Hall.

\section{Information about the author: Svitlana Vavilina,}

$\mathrm{PhD}$ of Pedagogical Sciences, Associate Professor, Department of Foreign Languages for Specific Purposes,

Zaporizhzhia National University 66, Zhukovsky str., Zaporizhzhia, 69000, Ukraine

ORCID ID: orcid.org/0000-0001-6200-1330 